\title{
Association of Cholesteryl Ester Transfer Protein-TaqlB Polymorphyisms with HDL Cholesterol Levels and the Risk of Coronary Artery Disease
}

One paper is published as an original article in this journal ( $\mathrm{p}----$ to----). The same results have already been reported elsewhere by many investigators. I would like to briefly review reversed cholesterol transport from the aspect of CETP.

Cholesteryl ester transfer protein (CETP) facilitates the exchange of triglycerides and cholesteryl esters among lipoprotein particles, a key step in reverse cholesterol transport in humans. Genetic variants at the CETP locus have been shown to be associated with CETP activity and mass, as well as plasma high density lipoprotein cholesterol (HDL-C). Hence, CETP gene polymorphisms may alter susceptibility to atherosclerosis.

The TaqIB restriction fragment length polymorphism in the CETP gene with two alleles, B1 and B2, has been investigated in relation to lipid variables and the risk of coronary artery disease (CAD) in quite a large number of studies. B2 carriers have reduced levels of plasma CETP and increased levels of HDL-C and of other HDL-related lipid variables. These effects of the polymorphism on plasma HDL-C are independent of metabolic factors that are known to regulate HDL-C levels. However, several studies have shown that the presence of the $\mathrm{B} 2 \mathrm{~B} 2$ genotype did not result in increased HDL-C in smokers, whereas the difference between B1B1 and B2B2 individuals is diminished in obese subjects ${ }^{1,2)}$. The effect of B2 on plasma HDL-C was absent in nondrinkers but increased commensurably with higher values of alcohol consumption $^{2,3)}$.

In the Framingham Offspring Study, the B2 allele was associated with increased levels of HDL-C, decreased CETP activity, and reduced CAD risk for men having the B2B2 genotype ${ }^{4)}$. In type 2 diabetic patients, the B2 allele was associated in a dose-dependent fashion with higher HDL-C and lower CETP concentrations. Then, the prevalence of macrovascular complications, such as CAD, arteriosclerosis obliterans, and cerebral vascular disease, was significantly higher in subjects with the B1B1 genotype ${ }^{5)}$. These data indicated that the protective effect of the B2 allele was due in part to its association with HDL-C levels, and the $\mathrm{B} 1 \mathrm{~B} 1$ genotype might be a genetic risk factor for CAD; however, others reported that carriers of the B2 allele had higher HDL-C concentrations, but did not have a lower risk of $\mathrm{CAD}^{6}$. In a population-based study, a common CETP promoter polymorphism such as TaqIB, which beneficially contributes to higher HDL-C, is paradoxically associated with increased incidence of $\mathrm{CAD}^{7)}$. CETP deficiency is considered a physiological state of impaired reverse cholesterol transport, which may lead to the development of atherosclerosis despite high HDL-C levels ${ }^{8}$. Thus, there is the possibility that CETP gene variation may affect coronary risk apart from the level of HDL-C.

\section{References}

1) Freeman DJ, Griffin BA, Holmes AP, Lindsay GM, Gaffney D, Packard CJ, and Shepherd J: Regulation of plasma HDL cholesterol and subfraction distribution by genetic and environmental factors. Associations between the TaqIB RFLP in the CETP gene and smoking and obesity. Arterioscler Thromb, 1994; 14:336-344

2) Tsujita $Y$, Nakamura $Y$, Zhang Q, Tamaki S, Nozaki A, Amamoto K, Kadowaki T, Kita Y, Okamura T, Horie M, and Ueshima $\mathrm{H}$ : The association between high-density lipoprotein cholesterol level and cholesteryl ester transfer protein TaqIB gene polymorphism is influenced by alcohol drinking in a population-based sample. Atherosclerosis, 2006; Epub

3) Fumeron F, Betoulle D, Luc G, Behague I, Ricard S, Poirier O, Jemaa R, Evans A, Arveiler D, and Marques-Vidal P: Alcohol intake modulates the effect of a polymorphism of the cholesteryl ester transfer protein gene on plasma high density lipoprotein and risk of myocardinal infarction. J Clin Invest, 1995; 96:1664-1671

4) Ordovas JM, Cupples LA, Corella D, Otvos JD, Osgood D, Martinez A, Lahoz C, Coltell O, Wilson PW, and Schaefer EJ: Association of cholesteryl ester transfer proteinTaqIB polymorphism with variations in lipoprotein subclasses and coronary heart disease risk: the Framingham study. Arterioscler Thromb, 2000; 20:1323-1329

5) Kawasaki I, Tahara H, Emoto M, Shoji T, and Nishizawa Y: Relationship between TaqIB cholesteryl ester transfer protein gene polymorphism and macrovascular complications in Japanese patients with type 2 diabetes. Diabetes, 2002; 51:871-874

6) Liu S, Schmitz C, Stampfer MJ, Sacks F, Hennekens CH, Lindpaintner K, and Ridker PM: A prospective study of TaqIB polymorphism in the gene coding for cholesteryl ester transfer protein and risk of myocardial infarction in middle-aged men. Atherosclerosis, 2002; 161:469-474

7) Borggreve SE, Hillege HL, Wolffenbuttel BH, de Jong PE, Zuurman MW, van der Steege G, van Tol A, and Dullaart 
RP, PREVEND Study Group: An increased coronary risk is paradoxically associated with common cholesteryl ester transfer protein gene variations that relate to higher highdensity lipoprotein cholesterol: a population-based study. J Clin Endocrinol Metab, 2006; 91:3382-3388

8) Yamashita S, Maruyama T, Hirano K, Sakai N, Nakajima $\mathrm{N}$, and Matsuzawa Y: Molecular mechanisms, lipoprotein abnormalities and atherogenicity of hyperalphalipoproteinemia. Atherosclerosis, 2000; 152:271-285
Hidetoshi Kotake

Division of Diabetes and Metabolism, Japanese Red Cross Sendai Hospital, 2-43-3 Yagiyamahoncho, Taihaku, Sendai 982-8501, Japan. 